\title{
DESAIN KOLIMATOR TIPE TABUNG UNTUK PENYEDIAAN BERKAS RADIOGRAFI DENGAN SUMBER GENERATOR NETRON
}

\author{
Yohannes Sardjono \\ Pusat Teknologi Akselerator dan Proses Bahan - BATAN \\ Alexander Agung, Ammi Noor Baits \\ Teknik Fisika UGM Yogyakarta
}

\begin{abstract}
AKSTRAK
DESAIN KOLIMATOR TIPE TABUNG UNTUK PENYEDIAAN BERKAS RADIOGRAFI DENGAN SUMBER GENERATOR NETRON. Telah dilakukan desain kolimator untuk penyediaan berkas radiografi netron dengan sumber generator netron. Kolimator ini berguna untuk mendapatkan fluks netron termal yang optimal dengan pengotor radiasi (netron epitermal dan gamma) yang sekecil-kecilnya. Proses desain dilakukan dengan melakukan simulasi menggunakan Monte Carlo N-Particle (MCNP) code untuk menghitung tally berupa fluks netron dan laju dosis ekuivalen. Desain kolimator yang dipilih adalah jenis tabung yang tersusun dari material moderator parafin, reflektor grafit, dan kolimator wall alumunium. Parameter optimasi desain adalah panjang kolimator 4 - $8 \mathrm{~cm}$, dengan interval 1 $\mathrm{cm}$, jenis bahan moderator (parafin, grafit, berilium, dan air), jenis beam filter adalah timbal, dan material aperture adalah boron atau kadmium. Kriteria penerimaan adalah fluks netron termal $10^{3}-10^{6} \mathrm{n} \cdot \mathrm{cm}^{-2} \cdot \mathrm{s}^{-1}, \mathrm{n} / \mathrm{\gamma}$ ratio $\geq 10^{6}$ $n . \mathrm{cm}^{-2} \cdot m R^{-1}$ dan $\mathrm{Cd}$ ratio > 2. Untuk keselamatan lingkungan digunakan parafin sebagai biological shielding dan timbal sebagai casing. Dari hasil perhitungan optimasi desain dapat diperoleh bahwa kolimator dengan sumber generator nuetron menghasilkan keluaran fluks netron termal $4.67 \pm 0.5981 \times 10^{3} \mathrm{n} . \mathrm{cm}^{-2} \cdot \mathrm{s}^{-1}$, rasio netron-gamma $(\mathrm{n} / \mathrm{\gamma}) \geq(1.56 \pm$ 0,000111) $10^{6} \mathrm{n} \cdot \mathrm{cm}^{-2} \mathrm{mR}^{-1}$ dan laju dosis ekuivalen pada jarak $10 \mathrm{~cm}$ dari permukaan fasilitas adalah 0,0378 - 0,0521 $\mathrm{mR} / \mathrm{jam}$.
\end{abstract}

Kata kunci : MCNP, generator netron, kolimator, fluks netron termal, Cd ratio, rasio $\mathrm{n} / \mathrm{V}$

\section{ABSTRACT}

CYLINDRICAL COLLIMATOR DESIGN TO PROVIDE NEUTRON RADIOGRAPHY FROM NEUTRON GENERATOR SOURCE. The collimator design to provide neutron radiography from neutron generator source has been done. Collimator is used to gain optimum thermal neutron flux with radiation contaminant (epitermal neutron and gamma) as low as possible. The design process was done by simulation using Monte Carlo N-Particle (MCNP) Code. The results are tallies that indicate neutron flux and equivalent dose rate. In this research, cylindrical collimator was used which construct of paraffin as moderator, graphite as reflector, and Al as wall. Author did some variations on certain components such as length $4-8 \mathrm{~cm}$, with interval of $1 \mathrm{~cm}$, moderator materials (paraffin, light water, Graphite, and berilium), lead beam filter thick, and aperture material (boron or Cadmium). There are three criteria for this design requirement: thermal neutron flux $10^{3}-10^{6} \mathrm{n} \cdot \mathrm{cm}^{-2} \cdot \mathrm{s}^{-1}, \mathrm{n} / \mathrm{y}$ ratio $\geq 10^{6} \mathrm{n} \cdot \mathrm{cm}^{-2} \cdot \mathrm{mR}^{-1}$, and $\mathrm{Cd}$ ratio $>2$. The design was also done on biological shielding using paraffin and aluminum case. The design had output for thermal neutron of (4.67 \pm 0.5981).10 $10^{3} \mathrm{n} \cdot \mathrm{cm}^{-2} \cdot \mathrm{s}^{-1}$ and has $\mathrm{n} / \mathrm{y}$ ratio of $(1.56 \pm 0,000111) \cdot 10^{6} \mathrm{n} \mathrm{cm}^{-2} \mathrm{mR}^{-1}$. Equivalent dose rate at radius $10 \mathrm{~cm}$ from surface of the designed equipment was $0,0378 \mathrm{~s} / \mathrm{d} 0,0521 \mathrm{mR} / \mathrm{hour}$.

Keyword : MCNP, neutron generator source, collimator, thermal neutron flux, Cd ratio, $n / y$ ratio

\section{PENDAHULUAN}

Qerdasarkan Air Carriers Traffic Data And Accident/Incident Data yang dikeluarkan oleh Direktorat Jendral Perhubungan Udara - Direktorat Standar Keselamatan Udara (DSKU) selama 10 tahun 1995 - 2005 bahwa dalam 1 tahun rata-rata terjadi 6 kali kecelakaan, 12 kali kejadian pesawat terbang dan 13.943 .111 orang penumpang yang sukses menikmati jasa penerbangan tersebut. Dari beberapa kali kecelakaan dan kejadian tersebut bahwa rata-rata pertahun telah terjadi korban 44 orang meninggal dan 29 orang cedera. Untuk itu prioritas manajemen dan teknologi transportasi pada Agenda Riset Nasional ditekankan pada keselamatan, keamanan dan kesesuaian dengan komponen lokal. Keselamatan dan keamanan dalam transportasi salah satunya ditentukan dengan Nondestructive Inspection (NDI) Procedures seperti yang tercantum dalam Advisory Circular AC 145-6 approve maintenance organizations for composite and bonded aircraft structure revision : 0 April 1999 yang 
diterbitkan Dirjen Perhubungan Udara - DEPHUB RI bahwa dalam perbaikan dan perawatan harus disediakan banyak hal khususnya metode dan prosedur tak rusak (NDT) seperti radiografi netron, sinar gamma dan sinar-X, serta ultrasonic dan beberapa jenis peralatan tes yang lainnya ${ }^{[1]}$.

Pengujian tak merusak - NDT adalah metode pengujian sistem, struktur dan komponen dalam suatu industri dengan tidak mengubah keadaan fisik benda uji tersebut. Teknik yang digunakan adalah material uji diradiasi dengan memanfaatkan daya penetrasi radiasi materi target sehingga diperoleh rekaman pencitraan dari radiasi yang diterima materi target. Tujuan NDT adalah untuk mengetahui kandungan cacat pada suatu komponen. Uji tak rusak dengan netron radiografi adalah salah satu metode teknik nuklir yang memiliki daya saing dan keunggulan jika dibandingkan dengan radiografi sinar $\mathrm{x}$ maupun sinar gamma yaitu dapat digunakan untuk menginspeksi nomor atom ringan $\mathrm{H}$, Li dan boron dan bahkan dapat digunakan untuk menentukan radioisotop serta menentukan material yang nomor atomnya medium s.d. heavy metal seperti $\mathrm{Cd}, \mathrm{Sm}$, europium, gadolonium dan dysprosium. Hal ini disebabkan bahwa sifat interaksi hamburan netron dengan materi lewat inti sedang sinar $\mathrm{x}$ interaksi elektron yang berada di kulit atom.

Netron radiografi dengan sumber generator netron memiliki kelebihan selain dapat menekan biaya juga waktu inspeksi yang cepat karena sistem, struktur dan komponen (SSK) yang akan diinspeksi dapat dilakukan secara langsung (insitu). Syarat sumber generator netron harus memiliki fluks netron termal $10^{1}-10^{4} \mathrm{n} . \mathrm{cm}^{-2} . \mathrm{s}^{-1}$ dan radiasi gamma di permukaan sistem netron radiografi adalah maksimum $0,1 \mathrm{mR} / \mathrm{jam}$ dan beberapa syarat lainnya seperti nilai banding cadmium dan gamma, perbandingan panjang dan diameter kolimator dan pemilihan geometri kolimator $^{[2]}$.

Untuk memenuhi persyaratan tersebut maka dilakukan optimasi desain pembuatan kolimator agar disamping persyaratan terpenuhi juga sesuai dengan dimensi dan geometri SSK yang akan diinspeksi. Perhitungan optimasi desain dilakukan dengan paket komputer Monte Carlo N-Particle (MCNP) yang sudah establis penggunaan-nya untuk menghitung interaksi antara partikel netron dan netron maupun jenis-jenis partikel lainnya ${ }^{[3]}$. Optimasi desain dan pembuatan kolimator dilakukan dengan mensimulasi jenis dan geometri material penyusun kolimator seperti iluminator yang berfungsi untuk menyediakan sumber netron yang seragam biasanya terbuat dari grafit, beam filter yang berfungsi menghilangkan jenis radiasi yang tidak dinginkan dari sumber biasanya bahan yang digunakan adalah $\mathrm{Bi}, \mathrm{Pb}, \mathrm{Al}_{2} \mathrm{O}_{3}, \mathrm{SiO}_{2}$, aperture yang berfungsi untuk membatasi masuknya netron kedalam kolimator, gamma shielding yang berfungsi untuk mengurangi radiasi gamma dan bahan yang digunakan biasanya $\mathrm{Pb}$, collimator wall yang berfungsi untuk pengurung pancaran netron biasanya terbuat dari boron atau material dengan scattering cross section kecil, cleanup plates yang berfungsi sama seperti collimator wall sebagai pengurung pancaran netron biasanya terbuat dari boron dan terakhir adalah filling gas yang berfungsi untuk memperbaiki distribusi pancaran netron dan mengurangi hamburannya yang terbuat dari bahan helium ${ }^{[2,3]}$.

\section{BATASAN DAN OPTIMASI PARAMETER DESAIN}

Kegiatan teknologi adalah pentahapan kegiatan yang berkaitan dengan penelitian (research), pengembangan (development), perekayasaan (enginering) dan operasi (operation). Status kegiatan desain kolimator adalah berada dalam tahapan penelitian yang dalam hal ini mencakup kegiatan optimasi parameter desain yang terdapat dalam Tabel 2 agar batasan desain tercapai. Adapun batasan desain kolimator adalah seperti pada Tabel 1.

Tabel 1. Batasan desain optimasi parameter kolimator radiografi netron sumber generator netron.

\begin{tabular}{|c|l|c|}
\hline No & \multicolumn{1}{|c|}{ Parameter batasan desain kolimator } & Nilai batas \\
\hline 1 & Keluaran fluks netron termal setelah melewati kolimator & $10^{3}-10^{6} \mathrm{n} \cdot \mathrm{cm}^{-2} \cdot \mathrm{s}^{-1}$ \\
\hline 2 & Netron-gamma ratio $(n / \gamma)$ & $\geq 10^{6} \mathrm{n} \cdot \mathrm{cm}^{-2} \cdot \mathrm{mR}^{-1}$ \\
\hline 3 & Radiasi di permukaan fasilitas uji tak rusak & Maksimum $0,1 \mathrm{mR} / \mathrm{jam}$ \\
\hline
\end{tabular}


Tabel 2. Parameter optimasi desain kolimator

\begin{tabular}{|c|c|l|}
\hline No & Parameter batasan desain kolimator & \multicolumn{1}{c|}{ Nilai batas } \\
\hline 1 & Geometri & Tipe tabung \\
\hline 2 & SSK yang akan diuji & Homogen untuk setiap voxel (element volume) \\
\hline 3 & Material Moderator & berilium, $\mathrm{H}_{2} \mathrm{O}$, parafin, grafit, dan $\mathrm{D}_{2} \mathrm{O}$ \\
\hline 4 & Material Aperture & Kadmium dan boron \\
\hline 5 & Material Beam filter & Timbal $(\mathrm{Pb})$ \\
\hline 6 & Sumber netron & Generator netron dengan energi netron $3 \mathrm{MeV}$ \\
\hline
\end{tabular}

Dalam optimasi parameter desain dengan simulasi MCNP, rentang energi netron yang disediakan dalam program ini adalah antara $10^{-11}$ sampai $20 \mathrm{MeV}$ untuk semua isotop dan lebih dari $150 \mathrm{MeV}$ untuk beberapa isotop tertentu. Sementara rentang energi foton yang disediakan antara $1 \mathrm{keV}$ sampai $100 \mathrm{GeV}$, yang juga merupakan rentang yang sama bagi energi elektron. Adapun satuan dasar yang digunakan dalam MCNP adalah panjang (cm), energi (MeV), waktu (shake, $10^{-8}$ detik), temperature $(\mathrm{MeV}, \mathrm{kT})$, densitas atom (atom/barn- $\left.\mathrm{cm}\right)$, densitas $\left(\mathrm{g} / \mathrm{cm}^{3}\right)$, tampang lintang (barn, $10^{-24} \mathrm{~cm}^{2}$ ), jumlah pemanasan (MeV/tumbukan), dan rasio berat atom berdasarkan pada massa netron.

Dalam menjalankan program simulasi Monte Carlo, pengguna harus membuat file input yang selanjutnya dapat dibaca oleh MCNP. File tersebut berisi informasi tentang permasalahan yang hendak disimulasikan, meliputi spesifikasi geometri, penjelasan material dan evaluasi tampang-lintang yang dipilih, data posisi dan karakteristik sumber netron, foton, atau elektron, model hasil simulasi atau tally yang diinginkan dan beberapa variasi teknik-teknik reduksi yang digunakan untuk meningkatkan efisiensi. Struktur dari file masukan tersebut adalah message block (optional), lank Line Deliminer (optional), one Line Problem Tittle Card, cell Cards, blank Line Deliminer, data Cards dan blank Line Deliminer (optional).

Pustaka yang digunakan oleh program MCNP berupa data atomik dan inti dengan energi kontinyu yang meliputi interaksi-interaksi netron, foton yang diakibatkan oleh interaksi netron dengan materi, interaksi foton dengan materi maupun interaksi partikel lainnya dengan materi. Data-data atomik dan inti tersebut berupa tabeltabel yang terkumpul dalam suatu file direktori, XSDIR. Pengguna MCNP dapat melakukan modifikasi atas pustaka data atomik dan inti tersebut dengan data eksperimen yang dimiliki.

MCNP memiliki 5 langkah eksekusi yang masing-masing diberi nama modul sebagai berikut (kata dalam kurung adalah nama modulnya):

1. Memroses input file dari persoalan (IMCN).

2. Membuat plot geometri (PLOT).

3. Memroses tampang lintang (XACT).

4. Mensimulasi perjalanan partikel (MCRUN).

5. Membuat plot tally atau tampang lintang (MCPLOT).

Perjalanan netron dari sumber netron hingga pemanfaatan netron termal untuk keperluan radiografi dapat digambarkan pada Gambar 1 (Smith \& Meadows, 1991):

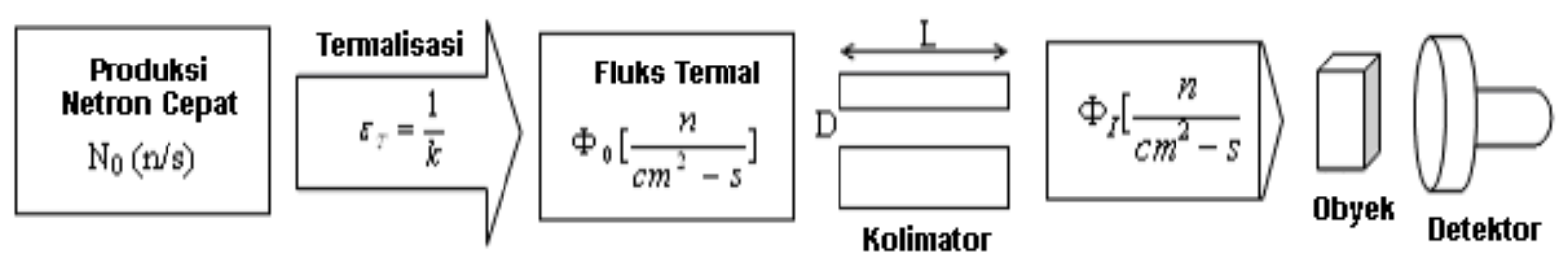

Gambar 1. Sketsa proses radiografi netron.

Pada proses ini, faktor yang berpengaruh adalah koefisien termalisasi, $\varepsilon_{\mathrm{T}}$. Umumya, rentang nilai $\varepsilon_{\mathrm{T}}$ dari $1 / 2$ $\%$ sampai $2 \%$ (nilai $\mathrm{K}$ antara 50 sampai 200). Desain kolimator yang dipilih harus memenuhi batasan desain seperti pada Tabel 1. 


\section{Peralatan Optimasi Parameter Desain}

Perangkat komputer (PC) dengan beberapa perangkat lunak seperti MCNP 4C, MCNP Visual Editor, Microsoft Word, Microsoft Excel, Notepad, Wordpad, Microsoft Visio versi 2003 dan Paint. Sedangkan tata cara optimasi desain adalah sebagai berikut:

Menguji kemampuan beberapa materi dalam melakukan termalisasi terhadap nuetron cepat. Pengujian ini dilakukan dengan membuat iluminator dari material grafit, parafin, $\mathrm{Be}$, dan $\mathrm{H}_{2} \mathrm{O}$. Model iluminator yang dibuat adalah seperti Gambar 2.

Kode 1 menunjukkan posisi sumber netron cepat - energi $3 \mathrm{MeV}$-, Kode 2 sampai dengan 10 merupakan materi yang diuji yang dipartisi bagian per-bagian, dengan tujuan untuk mengetahui keadaan fluks netron cepat dan netron termal pada tiap-tiap bagian, dan perubahan nilai fluks tersebut dari bagian ke bagian berikutnya. Kode 17 berfungsi sebagai reflektor, dalam hal ini digunakan bahan grafit.

Material moderator terbaik diketahui dengan cara membandingkan keadaan fluks netron cepat, epitermal, dan termal pada tiap-tiap sel.

Memodelkan sistem fisis desain kolimator untuk generator netron ke dalam format kode input agar dapat diproses oleh program MCNP.

Desain yang telah dibuat ada dua yaitu seperti pada Gambar 3 dan Gambar 4.

Model desain yang optimum ditentukan dengan mensimulasikan kedua model desain pada gambar 3 dan 4 melalui program MCNP, kemudian diperbandingkan keadaan netron di bagian kolimator. Parameter optimasinya adalah nilai $C d$ ratio dan fraksi $n / \gamma$ pada tiap-tiap bagian kolimator yang panjangnya antara $2 \mathrm{~cm}$ sampai dengan 9 $\mathrm{cm}$ dengan interval tiap bagian $1 \mathrm{~cm}$ sesuai dengan kemampuan dan waktu eksekusi perhitungan komputer yang digunakan.
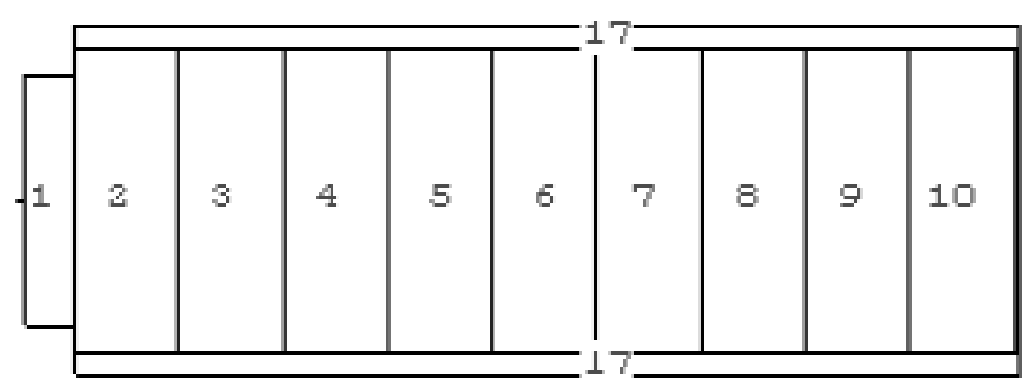

$Z$

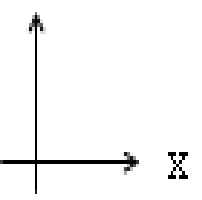

Gambar 2. Model iluminator untuk pengujian kemampuan materi dalam melakukan termalisasi terhadap netron cepat.

\section{Model I}

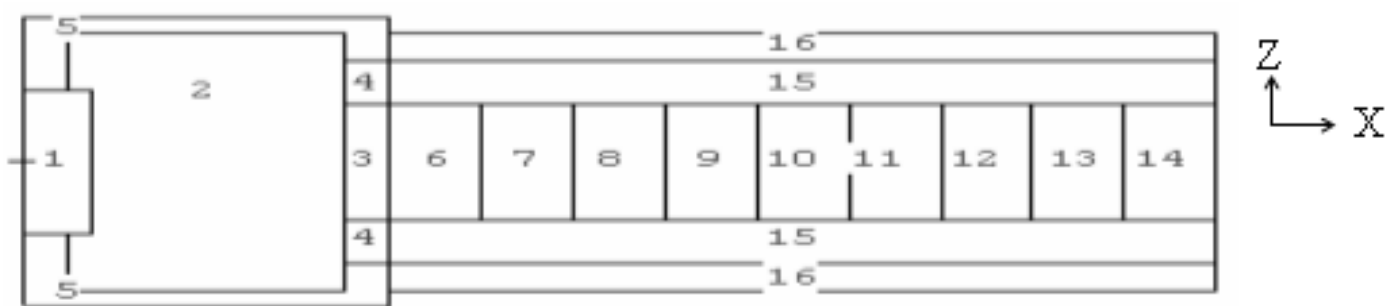

Gambar 3. Desain kolimator model I. 
Tabel 3. Keterangan parameter optimasi desain pada model I Gambar 3.

\begin{tabular}{|c|c|l|}
\hline Nomor & & \multicolumn{1}{|c|}{ Keterangan } \\
\hline 1 & $:$ & $\begin{array}{l}\text { Posisi sumber, } \\
\text { Sumber berbentuk silinder dengan diameter } 10 \mathrm{~cm} .\end{array}$ \\
\hline 2 & $:$ & $\begin{array}{l}\text { Illuminator, } \\
\text { Iluminator berbentuk silinder dengan ketebalan } 10 \mathrm{~cm} \text { dan diameter } 12 \mathrm{~cm} \text {, dengan } \\
\text { bahan moderator. }\end{array}$ \\
\hline 3 & $:$ & $\begin{array}{l}\text { Beam filter, } \\
\text { Bahan beam filter yang digunakan adalah } \mathrm{Pb} \text { dengan diameter } 5 \mathrm{~cm} \text { dan tebal } 1 \mathrm{~cm} .\end{array}$ \\
\hline 4 & $:$ & $\begin{array}{l}\text { Aperture, } \\
\text { Bahan yang digunakan untuk Aperture adalah boron dengan diameter luar } 7 \mathrm{~cm} \text { dan } \\
\text { tebal } 1 \mathrm{~cm} .\end{array}$ \\
\hline $6-14$ & $:$ & $\begin{array}{l}\text { Shield, } \\
\text { Bahan yang digunakan adalah Pb dengan ketebalan } 1 \mathrm{~cm}\end{array}$ \\
\hline 15 dan 16 & $: \begin{array}{l}\text { Kolimator } \\
\text { Bagian kolimator berisi bahan moderator sebagaimana yang digunakan untuk } \\
\text { illuminator }\end{array}$ \\
\hline $\begin{array}{l}\text { Collimator wall, } \\
\text { bahan yang digunakan adalan grafit berlapis Al, dengan ketebalan masing-masing } \\
1 \mathrm{~cm} \text { dan } 0,5 \mathrm{~cm} .\end{array}$ \\
\hline
\end{tabular}

\section{Model II}

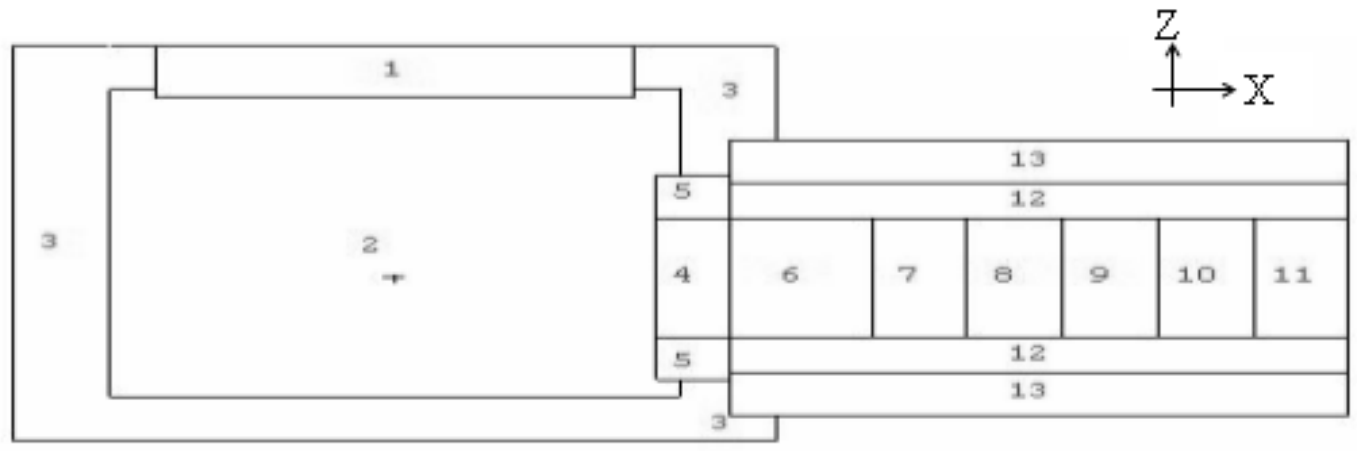

Gambar 4. Desain kolimator model II.

Tabel 4. Keterangan parameter optimasi desain pada model II Gambar 4.

\begin{tabular}{|c|l|l|}
\hline Nomor & & \multicolumn{1}{|c|}{ Keterangan } \\
\hline 1 & $:$ & $\begin{array}{l}\text { Posisi sumber, } \\
\text { Sumber berbentuk silinder dengan diameter } 10 \mathrm{~cm} .\end{array}$ \\
\hline 2 & $:$ & $\begin{array}{l}\text { Illuminator, } \\
\text { Iluminator berbentuk silinder dengan ketebalan } 10 \mathrm{~cm} \text { dan diameter } 12 \mathrm{~cm} \text {, dengan } \\
\text { bahan moderator. }\end{array}$ \\
\hline 3 & $:$ & $\begin{array}{l}\text { Shield, } \\
\text { Bahan yang digunakan adalah Pb dengan ketebalan } 1 \mathrm{~cm}\end{array}$ \\
\hline 4 & $: \begin{array}{l}\text { Beam Filter, } \\
\text { Bahan beam filter yang digunakan adalah Pb dengan diameter } 5 \mathrm{~cm} \text { (sesuai dengan } \\
\text { dimensi dari diameter target tritium) dan tebal } 1 \mathrm{~cm} \text { (sesuai hasil perhitungan optimasi } \\
\text { desain). }\end{array}$ \\
\hline
\end{tabular}




\begin{tabular}{|c|l|l|}
\hline Nomor & & \multicolumn{1}{|c|}{ Keterangan } \\
\hline 5 & $:$ & $\begin{array}{l}\text { Aperture, } \\
\text { Bahan yang digunakan untuk Aperture adalah boron dengan diameter luar } 7 \mathrm{~cm} \text { dan } \\
\text { tebal } 1 \mathrm{~cm} \text { (sesuai hasil optimasi desain) }\end{array}$ \\
\hline $6 \mathrm{~s} / \mathrm{d}$ & $:$ & $\begin{array}{l}\text { Kolimator, } \\
\text { Bagian kolimator berisi bahan moderator sebagaimana yang digunakan untuk illuminator }\end{array}$ \\
\hline 11 & $:$ & $\begin{array}{l}\text { Collimator wall, } \\
\text { bahan yang digunakan adalan grafit berlapis Al, dengan ketebalan masing-masing } 1 \mathrm{~cm} \\
\text { dan } 0,5 \mathrm{~cm} \text { (sesuai hasil optimasi desain). }\end{array}$ \\
\hline
\end{tabular}

Mencari tebal beam filter, jenis material aperture dan panjang kolimator yang optimum. Tebal beam filter optimum dicari dengan memvariasikan tebal beam filter untuk desain kolimator panjang efektifnya dengan rentang ketebalan $0,0-1,0 \mathrm{~cm}$ dan interval $0,25 \mathrm{~cm}$. Tebal beam filter optimum ditentukan dengan mengamati parameter rasio netron-gamma $(n / \gamma$ ratio). Sementara penentuan jenis material aperture dilakukan dengan memvariasikan material boron dan kadmium dengan ukuran geometri sebagaimana yang disebutkan pada keterangan Gambar 3 dan 4 panjang kolimator optimum dicari pada variasi $4-8 \mathrm{~cm}$ sesuai dengan jenis dan hasil perhitungan.

Membuat perisai dan menentukan tebalnya. Tebal perisai ditentukan agar laju dosis yang diukur memenuhi persyaratan batas ambang laju dosis radiasi yang diizinkan, yaitu laju dosis radiasi total pada radius $10 \mathrm{~cm}$ dari permukaan alat adalah $0,1 \mathrm{mrem} / \mathrm{jam}$. Menghitung berat desain yang ditetapkan dan yang terakhir adalah membuat gambar desain kolimator.

\section{Pemodelan Sistem Kolimator Dalam Kode Input Program MCNP}

Contoh kode input model I pada gambar 4.2 adalah sebagai berikut:

\section{UJI MODEL I}

c cell cards

$\begin{array}{llllll}1 & 0 & -1 & 8 & -10 & \text { \$sumber }\end{array}$

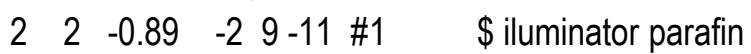

$3 \quad 1 \quad-11.34 \quad-3 \quad 8-12$ \#1 \#2 \#4 \#5 \$ shield $\mathrm{Pb}$

$\begin{array}{llllllll}4 & 3 & -2.3 & 4 & -5 & 11 & -12 \quad \text { \$ apercer Boron }\end{array}$

$\begin{array}{lllllll}5 & 1 & -11.34 & -4 & 11 & -12 \quad \text { \$ beam filter } \mathrm{Pb}\end{array}$

$\begin{array}{llllllll}6 & 2 & -0.89 & -4 & 12 & -14 & \text { \$ Parafin }\end{array}$

$\begin{array}{llllllll}7 & 2 & -0.89 & -4 & 14 & -15 & \text { \$ Parafin }\end{array}$

$\begin{array}{llllll}8 & 2 & -0.89 & -4 & 15 & -16\end{array}$

$\begin{array}{llllll}9 & 2 & -0.89 & -4 & 16 & -17\end{array}$

$\begin{array}{llllll}10 & 2 & -0.89 & -4 & 17 & -18\end{array}$

$\begin{array}{llllll}11 & 2 & -0.89 & -4 & 18 & -19\end{array}$

$\begin{array}{llllll}12 & 2 & -0.89 & -4 & 19 & -20\end{array}$

$\begin{array}{llllll}13 & 2 & -0.89 & -4 & 20 & -21\end{array}$

$\begin{array}{llllll}14 & 2 & -0.89 & -4 & 21 & -22\end{array}$

$\begin{array}{lllllll}15 & 2 & -0.89 & -4 & 22 & -23 & \text { \$Parafin }\end{array}$

$16 \quad 4 \quad-1.67 \quad 4-6 \quad 12-24$ \$COLIMATOR WALL Grafit

$\begin{array}{llllll}17 & 5 & -2.699 & 6-7 & 12 & -24\end{array}$ \$COLIMATOR WALL Al

180 \#1 \#2 \#3 \#4 \#5 \#6 \#7 \#8 \#9 \#10 \#11 \#12 \#13 \#14 \#15 \#16 \#17

c muka

1 cx 5 \$sumber

$2 \mathrm{cx} 6 \quad \$ p b$ filter 
3 cx 7

4 cx 2.5

5 cx 3.5

$6 \mathrm{cx} 3.5$

$7 \mathrm{cx} 4.0$

$8 \mathrm{px} 0$

$9 \mathrm{px} 1$

$10 \mathrm{px} 1.5$

$11 \mathrm{px} 7$

$12 \mathrm{px} 8$ \$perbatasan

14 px 9

15 px 10

16 px 11

17 px 12

18 px 13

19 px 14

20 px 15

21 px 16

22 px 17

23 px 18

mode $n p$

m1 82207.60 $1 \$ P b$

m2 1001.60c 0.67533 6000.60c 0.32467 \$Paraffin

m3 5010.60 1 \$Boron

m4 6000.60C 1 \$grafit

m5 $13027.60 \mathrm{C} 1$ \$Al

imp:p $117 R 0$

sdef erg=3 par=1 cell=1 pos=1.4 00 ara=78.5 dir=1 vec=1 00

nps 10000

f5:p $\quad 9.0 \quad 0.0 \quad 0.02 .30$

$\begin{array}{llll}10.0 & 0.0 & 0.0 & 2.30\end{array}$

$\begin{array}{llll}11.0 & 0.0 & 0.0 & 2.30\end{array}$

de5 0.010 .0150 .020 .030 .040 .050 .060 .08

0.10 .150 .20 .30 .40 .50 .60 .811 .523456810

df5 2.78e-6 $1.11 \mathrm{e}-6 \quad 5.88 \mathrm{e}-7 \quad 2.56 \mathrm{e}-7 \quad 1.56 \mathrm{e}-7 \quad 1.20 \mathrm{e}-7 \quad 1.11 \mathrm{e}-7 \quad 1.20 \mathrm{e}-7 \quad 1.47 \mathrm{e}-7 \quad 2.38 \mathrm{e}-7$

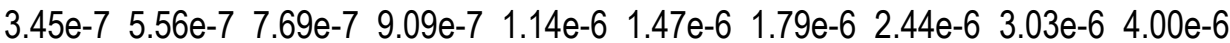

$4.76 \mathrm{e}-6 \quad 5.56 \mathrm{e}-6 \quad 6.25 \mathrm{e}-6 \quad 7.69 \mathrm{e}-6 \quad 9.09 \mathrm{e}-6$

f4:n 789101112131415

fm4 $1 \mathrm{e} 8$

e4 $\quad 5 e-7 \quad 1 e-2 \quad 1 \quad 3 \quad 4$

print 


\section{HASIL DAN PEMBAHASAN}

Pengujian ini dilakukan dengan memposisikan beberapa material di depan sumber. Material yang dipilih adalah grafit, parafin, $\mathrm{Be}$, dan $\mathrm{H}_{2} \mathrm{O}$ (air). Hasil perhitungan dapat dilihat pada Gambar 5 .

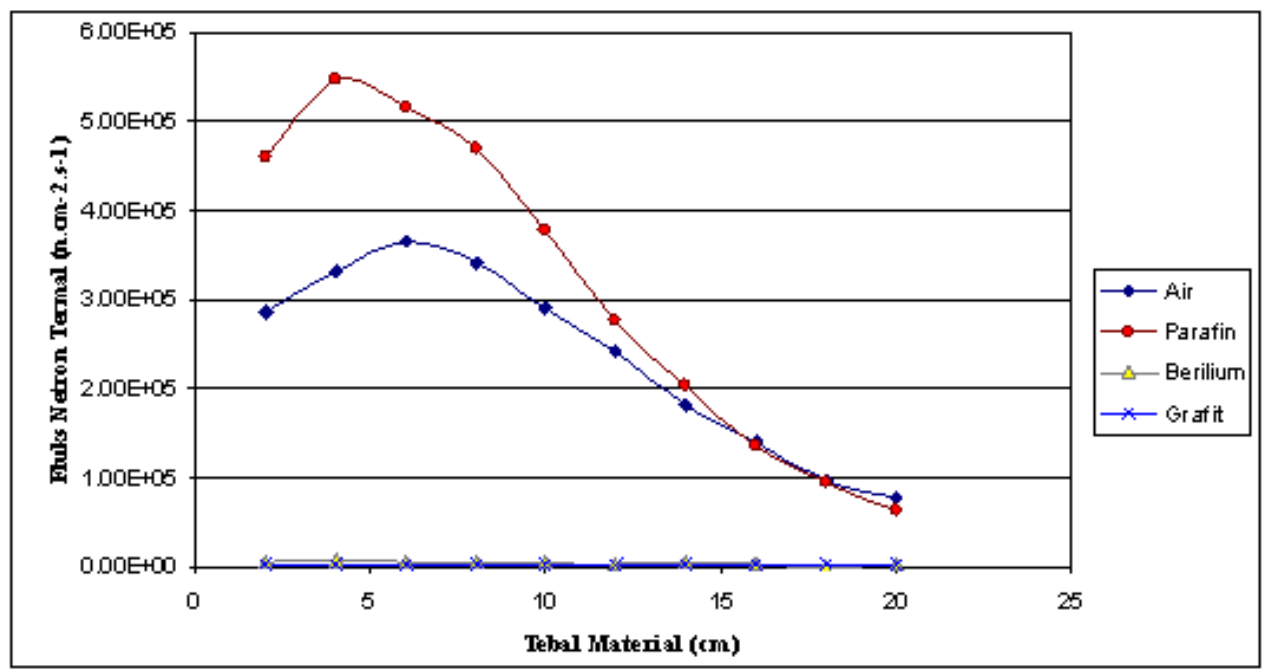

Gambar 5. Hasil perhitungan fluks netron termal pada beberapa material moderator.

Dari Gambar 5 dapat disimpulkan bahwa material yang memungkinkan untuk digunakan sebagai moderator adalah air dan parafin, karena hanya dua material ini yang menghasilkan fluks termal yang lebih tinggi dari pada fluks netron epitermal. Sementara hasil perbandingan material air dan parafin, material parafin dianggap lebih karena pada Gambar 5 ditunjukkan bahwa pada jarak yang sama, fluks netron termal yang dihasilkan dari peristiwa moderasi parafin lebih tinggi dibandingkan dengan air. Selain moveable, material fase padat dianggap lebih aman dibandingkan material fase cair. Dari sifat fisisnya, parafin lebih ringan dibanding air karena massa jenisnya yang lebih kecil.

\section{Hasil Pemilihan Model Desain Yang Lebih Optimum}

Parameter model yang diperbandingkan adalah nilai $C d$ ratio dan perbandingan fraksi $n / \gamma$ dari masingmasing model desain. Dari pengujian yang dilakukan diperoleh hasil sebagai berikut :

Dari hasil pada Tabel 5 dan 6 terlihat bahwa kedua desain memenuhi persyaratan perbandingan fraksi netron dengan dosis radiasi gamma, yaitu fraksi $n / \gamma \geq 10^{6} \mathrm{n} \cdot \mathrm{cm}^{-2} \cdot \mathrm{mR}^{-1}$. Penentu pemilihan model desain selanjutnya adalah nilai kadmium dimana dipersyaratkan nilainya $\geq 2$. Dari pada tabel 5 dan 6 , dapat disimpulkan bahwa model yang lebih optimum adalah model desain II.

Tabel 5. Hasil perhitungan fluks netron dan Cd Ratio pada desain Model I.

\begin{tabular}{|c|c|c|c|c|c|c|c|}
\hline \multirow{2}{*}{ No } & \multirow{2}{*}{$L(\mathrm{~cm})$} & \multicolumn{3}{|c|}{ Fluks $\left(\mathrm{n} . \mathrm{cm}^{-2} \cdot \mathrm{s}^{-1}\right)$} & \multirow{2}{*}{$\begin{array}{c}\text { Cd } \\
\text { Ratio }\end{array}$} & \multirow{2}{*}{$\begin{array}{c}\mathrm{D} \gamma \\
\left(\mathrm{mR} \cdot \mathrm{s}^{-1}\right)\end{array}$} & \multirow{2}{*}{$\begin{array}{c}\mathrm{n} / \boldsymbol{\gamma} \\
\left(\mathrm{n} . \mathrm{cm}^{-2} \mathrm{mR}\right)\end{array}$} \\
\hline & & Termal & Epitermal & Total & & & \\
\hline 1 & 2 & $1.23 E+05$ & $2.16 \mathrm{E}+05$ & $2.09 \mathrm{E}+06$ & 0,570 & $1.70 \mathrm{E}-02$ & $7.22 \mathrm{E}+06$ \\
\hline 2 & 3 & $1.29 \mathrm{E}+05$ & $1.83 \mathrm{E}+05$ & $1.74 \mathrm{E}+06$ & 0,706 & $1.26 \mathrm{E}-02$ & $1.03 E+07$ \\
\hline 3 & 4 & $1.13 \mathrm{E}+05$ & $1.38 \mathrm{E}+05$ & $1.42 E+06$ & 0,820 & $1.14 \mathrm{E}-02$ & $9.95 E+06$ \\
\hline 4 & 5 & $9.72 E+04$ & $1.29 E+05$ & $1.19 \mathrm{E}+06$ & 0,751 & $6.56 \mathrm{E}-03$ & $1.48 \mathrm{E}+07$ \\
\hline 5 & 6 & $7.98 \mathrm{E}+04$ & $1.16 \mathrm{E}+05$ & $9.69 \mathrm{E}+05$ & 0,689 & $7.03 \mathrm{E}-03$ & $1.13 E+07$ \\
\hline 6 & 7 & $6.09 \mathrm{E}+04$ & $8.08 \mathrm{E}+04$ & $7.67 \mathrm{E}+05$ & 0,753 & $6.18 \mathrm{E}-03$ & $9.85 E+06$ \\
\hline 7 & 8 & $5.00 \mathrm{E}+04$ & $6.20 \mathrm{E}+04$ & $6.22 E+05$ & 0,806 & $7.87 \mathrm{E}-03$ & $6.35 E+06$ \\
\hline 8 & 9 & $3.52 E+04$ & $5.75 \mathrm{E}+04$ & $5.04 \mathrm{E}+05$ & 0,612 & $7.51 \mathrm{E}-03$ & $4.69 \mathrm{E}+06$ \\
\hline
\end{tabular}


Tabel 6. Hasil perhiungan fluks netron dan Cd Ratio pada desain Model II.

\begin{tabular}{|c|c|c|c|c|c|c|c|}
\hline \multirow{2}{*}{ No } & \multirow{2}{*}{$\mathrm{L}(\mathrm{cm})$} & \multicolumn{3}{|c|}{ Fluks $\left(\mathrm{n} \mathrm{cm}^{-2} \cdot \mathrm{s}^{-1}\right)$} & \multirow{2}{*}{$\begin{array}{c}\text { Cd } \\
\text { Ratio }\end{array}$} & \multirow{2}{*}{$\begin{array}{c}D \gamma \\
\left(m R . s^{-1}\right)\end{array}$} & \multirow{2}{*}{$\begin{array}{c}\mathrm{n} / \gamma \\
\left.\text { (n.cm }{ }^{-2} / \mathrm{mR}\right)\end{array}$} \\
\hline & & Termal & Epitermal & Total & & & \\
\hline 1 & 2 & $2.76 \mathrm{E}+04$ & $1.24 \mathrm{E}+04$ & $5.74 \mathrm{E}+04$ & 2.21 & $9.81 \mathrm{E}-03$ & $2.81 \mathrm{E}+06$ \\
\hline 2 & 3 & $1.81 \mathrm{E}+04$ & $1.00 \mathrm{E}+04$ & $3.92 E+04$ & 1.80 & $6.43 \mathrm{E}-03$ & $2.81 \mathrm{E}+06$ \\
\hline 3 & 4 & $1.52 \mathrm{E}+04$ & $6.31 \mathrm{E}+03$ & $3.08 \mathrm{E}+04$ & 2.41 & $4.66 \mathrm{E}-03$ & $3.27 \mathrm{E}+06$ \\
\hline 4 & 5 & $5.43 E+03$ & $4.05 \mathrm{E}+03$ & $1.93 \mathrm{E}+04$ & 1.34 & $3.31 \mathrm{E}-03$ & $1.64 \mathrm{E}+06$ \\
\hline 5 & 6 & $6.15 E+03$ & $2.47 \mathrm{E}+03$ & $1.49 \mathrm{E}+04$ & 2.49 & $2.92 \mathrm{E}-03$ & $2.11 \mathrm{E}+06$ \\
\hline 6 & 7 & $6.68 \mathrm{E}+03$ & $1.68 \mathrm{E}+03$ & $1.38 \mathrm{E}+04$ & 3.98 & $2.23 \mathrm{E}-03$ & $3.00 \mathrm{E}+06$ \\
\hline 7 & 8 & $3.37 E+03$ & $2.32 E+03$ & $7.99 \mathrm{E}+03$ & 1.45 & $1.53 \mathrm{E}-03$ & $2.21 \mathrm{E}+06$ \\
\hline 8 & 9 & $1.34 \mathrm{E}+03$ & $8.89 E+02$ & $4.09 \mathrm{E}+03$ & 1.51 & $1.43 \mathrm{E}-03$ & $9.38 \mathrm{E}+05$ \\
\hline
\end{tabular}

Hasil Optimasi Parameter Desain Tebal Beam Filter, Jenis Material Aperture dan Panjang Bagian Kolimator

Material beam filter ditentukan, yaitu $\mathrm{Pb}$ sementara tebalnya divariasikan antara $0 \mathrm{~cm}-1 \mathrm{~cm}$ dengan interval $0,25 \mathrm{~cm}$ sesuai dengan kemampuan dan batasan fisis dari kode komputer yang digunakan. Sedangkan material Aperture yang divariasikan adalah $\mathrm{B}$ atau $\mathrm{Cd}$ dengan ketebalan sama dengan ketebalan filter. Jari-jari beam filter ditentukan yaitu $2,5 \mathrm{~cm}$ sedangkan jari-jari Aperture bagian luar adalah $3,5 \mathrm{~cm}$. Panjang kolimator divariasikan antara 3 sampai $8 \mathrm{~cm}$ dengan interval $1 \mathrm{~cm}$. Hasil simulasi ditunjukkan pada Tabel 5 .

Dari Tabel 6 desain yang dipilih adalah desain nomor 8, dengan kriteria panjang kolimator $6 \mathrm{~cm}$, tebal Beam Filter $\mathrm{Pb} 0,75 \mathrm{~cm}$ dan material Aperture boron dengan ketebalan yang sama, fluks netron termal yang dihasilkan sebesar $4,67 \cdot 10^{3} \mathrm{n} \cdot \mathrm{cm}^{-2} \cdot \mathrm{s}^{-1}$ dan fraksi netron gamma sebesar $1,56 \cdot 10^{6} \mathrm{n} \cdot \mathrm{cm}^{-2} \cdot \mathrm{mR}^{-1}$.

\section{Hasil Optimasi Desain Tebal Perisai}

Perisai diperlukan untuk melindungi operator dari bahaya paparan radiasi. Berdasarkan IAEA Safety Series No. 9 tahun 1962, nilai ambang laju dosis radiasi yang diizinkan pada radius $10 \mathrm{~cm}$ dari permukaan alat adalah 0,1 $\mathrm{mR} / \mathrm{jam}$.

Untuk mengungkung radiasi netron dan gamma, desain perisai ini menggunakan bahan moderator parafin dan casing $\mathrm{Pb}$. Perhitungan MCNP dilakukan dengan memasang detektor titik pada jarak $10 \mathrm{~cm}$ sesuai dengan prinsip As Low As Radiation Acceptance (ALARA) dan jarak terdekat dari permukaan perisai, pada arah samping, depan, dan atas jendela generator netron.

Dari Tabel 7 dapat ditentukan bahwa agar desain alat ini memenuhi persyaratan batas ambang yang diizinkan maka dibutuhkan perisai desain berbahan parafin dengan ketebalan $50 \mathrm{~cm}$ dan casing $\mathrm{Pb}$ dengan ketebalan $7 \mathrm{~cm}$. Perisai ini dapat mengurangi laju dosis total pada jarak $10 \mathrm{~cm}$ dari permukaan alat di bawah batas ambang yang diizinkan, dengan rincian: laju dosis posisi samping $0,0452 \mathrm{mR} / \mathrm{h}$, atas $0,0378 \mathrm{mR} / \mathrm{h}$, dan depan $0,0521 \mathrm{mR} / \mathrm{h}$.

\section{Hasil Optimasi Massa Sistem Radiografi}

Perhitungan massa alat tidak melibatkan massa generator netron, karena sumber netron dianggap bagian terpisah dari desain kolimator.

Tabel 7. Variasi laju dosis radiasi terhadap tebal perisai.

\begin{tabular}{|c|c|c|c|c|}
\hline $\begin{array}{c}\text { Tebal Perisai } \\
(\mathrm{cm})\end{array}$ & $\begin{array}{c}\text { Posisi } \\
\text { Detektor }\end{array}$ & $\begin{array}{c}\text { Laju Dosis Netron } \\
(\text { mrem/jam })\end{array}$ & $\begin{array}{c}\text { Laju Dosis Gamma } \\
(\text { mrem/jam })\end{array}$ & $\begin{array}{c}\text { Laju Dosis Total } \\
(\text { mrem/jam })\end{array}$ \\
\hline \multirow{3}{*}{30} & Samping & $2.58 \mathrm{E}+00$ & $3.65 \mathrm{E}-01$ & $2.95 \mathrm{E}+00$ \\
\cline { 2 - 5 } & Atas & $1.92 \mathrm{E}-02$ & $1.37 \mathrm{E}-01$ & $1.56 \mathrm{E}-01$ \\
\cline { 2 - 5 } & Depan & $5.64 \mathrm{E}+00$ & $1.63 \mathrm{E}-01$ & $5.80 \mathrm{E}+00$ \\
\hline \multirow{3}{*}{40} & Samping & $2.89 \mathrm{E}-04$ & $1.90 \mathrm{E}-01$ & $1.90 \mathrm{E}-01$ \\
\cline { 2 - 5 } & Atas & $7.37 \mathrm{E}-03$ & $7.82 \mathrm{E}-02$ & $8.56 \mathrm{E}-02$ \\
\cline { 2 - 5 } & Depan & $3.78 \mathrm{E}-01$ & $1.78 \mathrm{E}-01$ & $5.56 \mathrm{E}-01$ \\
\hline
\end{tabular}




\begin{tabular}{|c|c|c|c|c|}
\hline $\begin{array}{c}\text { Tebal Perisai } \\
(\mathrm{cm})\end{array}$ & $\begin{array}{c}\text { Posisi } \\
\text { Detektor }\end{array}$ & $\begin{array}{c}\text { Laju Dosis Netron } \\
(\mathrm{mrem} / \mathrm{jam})\end{array}$ & $\begin{array}{c}\text { Laju Dosis Gamma } \\
(\mathrm{mrem} / \mathrm{jam})\end{array}$ & $\begin{array}{c}\text { Laju Dosis Total } \\
(\mathrm{mrem} / \mathrm{jam})\end{array}$ \\
\hline \multirow{3}{*}{50} & Samping & $8.82 \mathrm{E}-06$ & $4.52 \mathrm{E}-02$ & $4.52 \mathrm{E}-02$ \\
\cline { 2 - 5 } & Atas & $4.22 \mathrm{E}-03$ & $3.36 \mathrm{E}-02$ & $3.78 \mathrm{E}-02$ \\
\cline { 2 - 5 } & Depan & $1.73 \mathrm{E}-02$ & $3.47 \mathrm{E}-02$ & $5.21 \mathrm{E}-02$ \\
\hline
\end{tabular}

Tabel 8. Daftar material desain dan massanya.

\begin{tabular}{|c|c|c|c|c|c|}
\hline No & Bagian & Bahan & Volume $\left(\mathrm{cm}^{3}\right)$ & Massa jenis $\left(\mathrm{g} / \mathrm{cm}^{3}\right)$ & Massa $(\mathrm{g})$ \\
\hline 1 & Moderator & Parafin & 1091,15 & 0,89 & 971,1235 \\
\hline 2 & Shield & $\mathrm{Pb}$ & 615,051 & 11,34 & 6974,678 \\
\hline 3 & Beam Filter & $\mathrm{Pb}$ & 14,719 & 11,34 & 166,9135 \\
\hline 4 & Aperture & Boron & 14,13 & 2,3 & 32,499 \\
\hline & Collimator Wall & & & & 1,3 \\
\cline { 2 - 6 } & Bagian dalam & Grafit & 113,04 & 1,67 & 198,777 \\
\cline { 2 - 6 } 5 & Bagian luar & Al & 70,65 & 2,699 & 104,798 \\
\hline 6 & Bagian kolimasi & Parafin & 117,75 & 0,89 & 8629,473 \\
\hline \multicolumn{7}{|c|}{ Sub total } & & 436824,193 \\
\hline \multirow{7}{*}{7} & \multirow{7}{*}{ Perisai } & Parafin & $490.813,7$ & 0,89 & 2150424,045 \\
\cline { 2 - 6 } & Pb & $189.631,75$ & 11,34 & $\mathbf{2 5 9 5 8 7 9 , 1 1 6}$ \\
\hline
\end{tabular}

Dari Tabel 8 dapat dilihat bahwa massa kolimator adalah $8,629 \mathrm{~kg}$, massa totalnya $2.595 .879,116 \mathrm{~g}$. Gambar teknik hasil desain seperti pada Gambar 6, Gambar 7 dan Gambar 8.

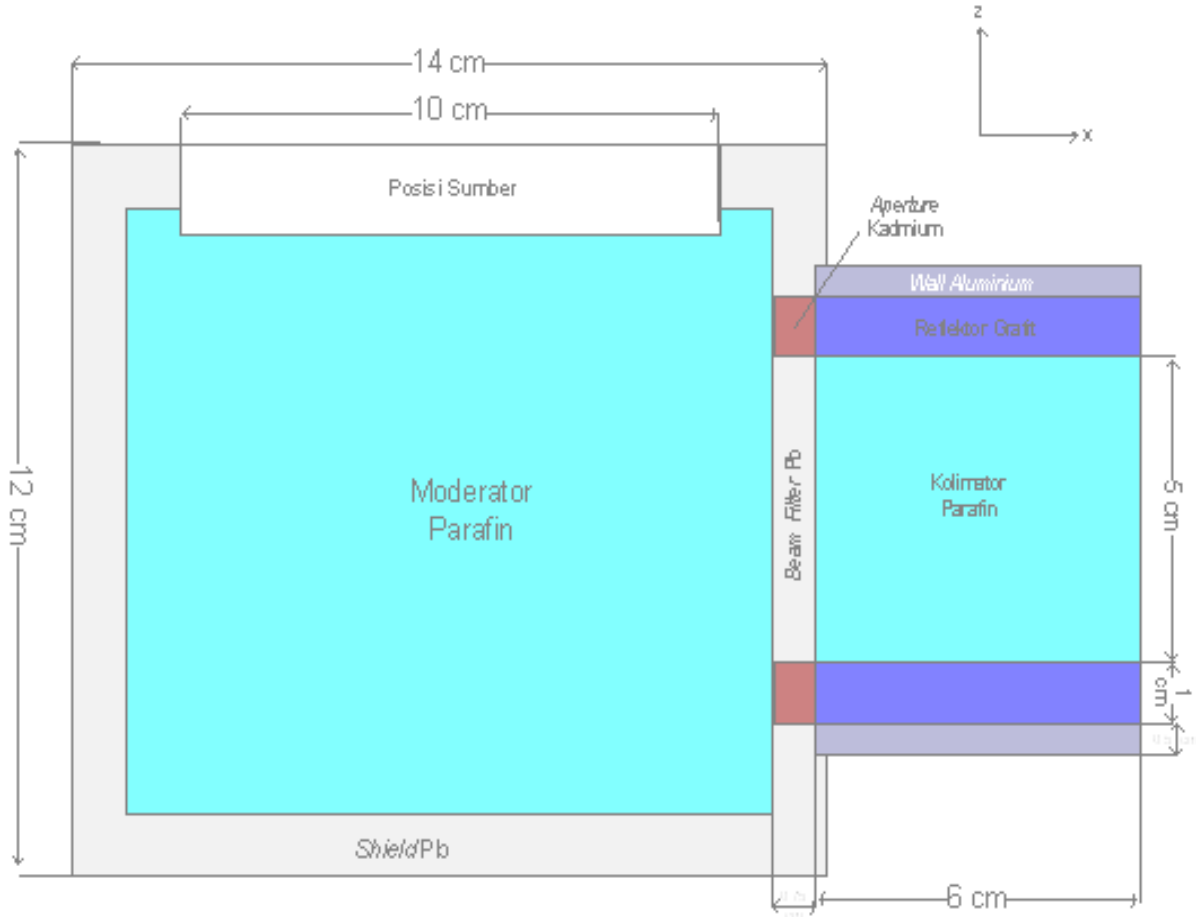

Gambar 6. Sistem fasilitas radiografi dan kolimator netron tampak samping. 


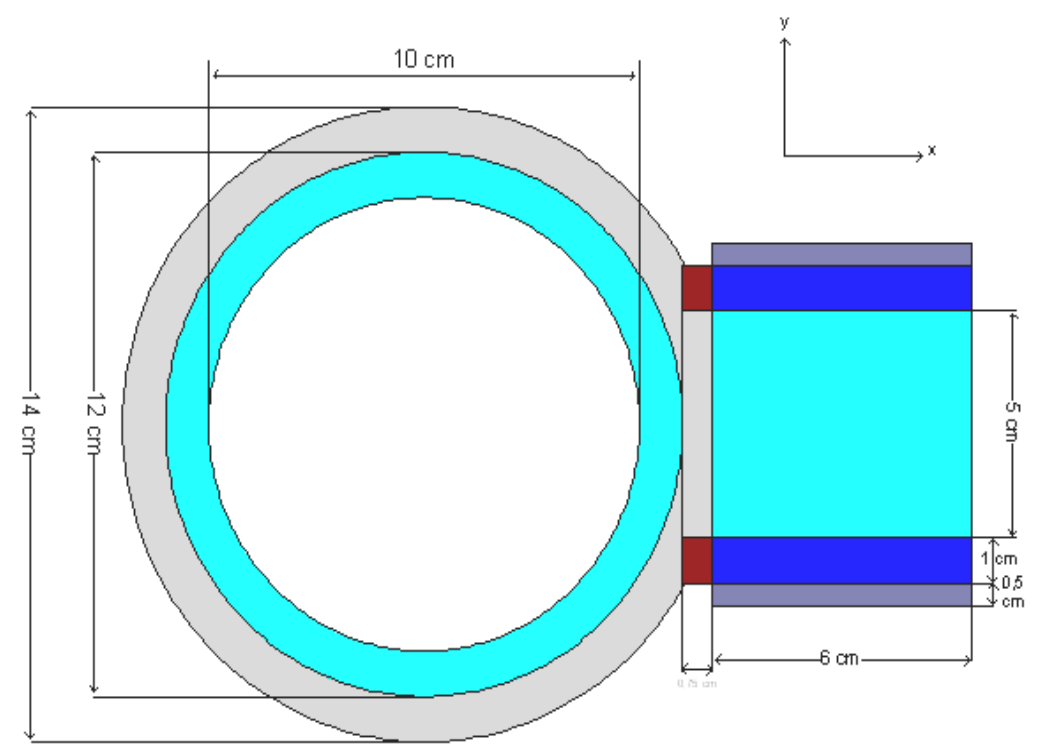

Gambar 7. Sistem fasilitas radiografi dan kolimator netron tampak atas.

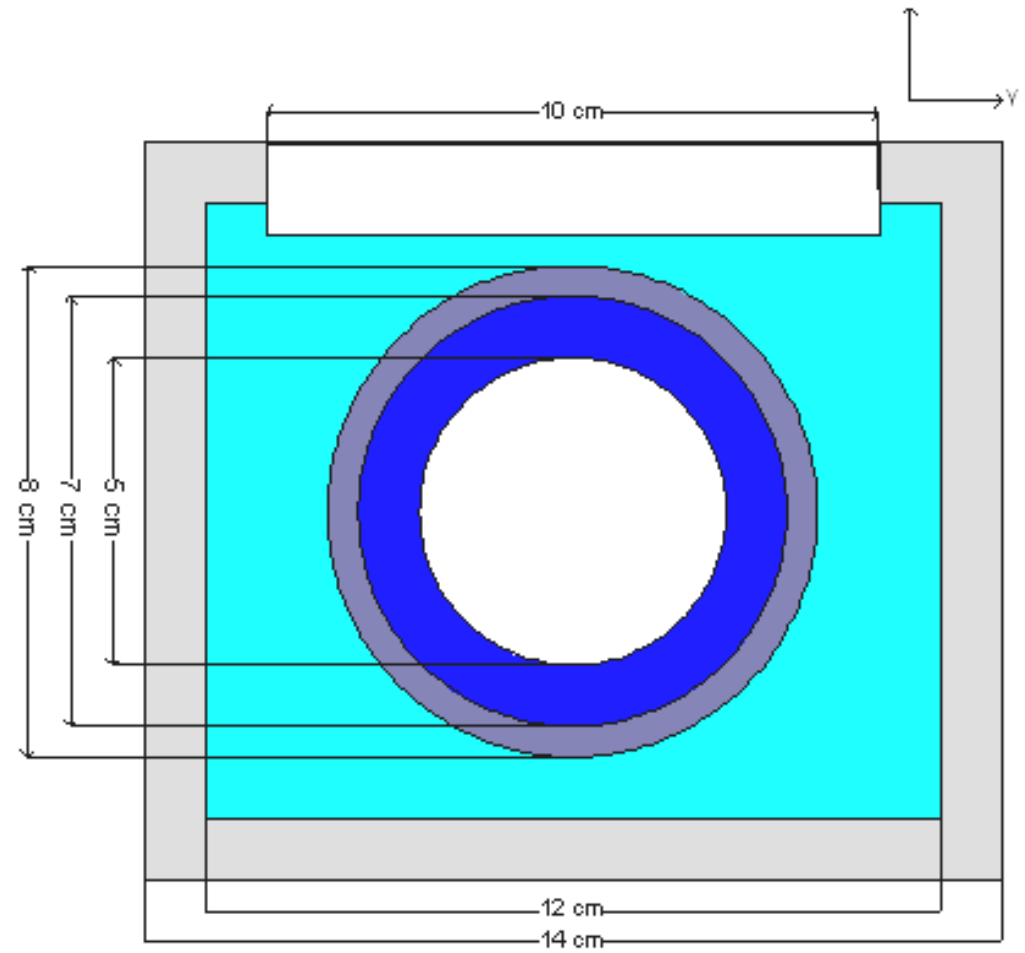

Gambar 8. Sistem fasilitas radiografi dan kolimator netron tampak depan.

\section{KESIMPULAN DAN SARAN}

Berdasarkan hasil penelitian yang telah dilakukan, maka dapat disimpulkan sebagai berikut : Fluks netron optimal sebesar $(4.67 \pm 0.5981) \cdot 10^{3} \mathrm{n} . \mathrm{cm}^{-2} . \mathrm{s}^{-1}$ dihasilkan pada desain kolimator dengan filter $\mathrm{Pb}$, Aperture $\mathrm{B}$, dengan tebal masing-masing $0,75 \mathrm{~cm}$ dan panjang kolimator $6 \mathrm{~cm}$. Paparan gamma pada image plane untuk desain kolimator yang dipilih sebesar $(2.99 \pm 0.081659) \cdot 10^{-3} \mathrm{mR} / \mathrm{s}$. Nilai rasio netron gamma pada desain kolimator yang dipilih sebesar $(1.56 \pm 0,0001) \cdot 10^{6} \mathrm{n} \mathrm{cm}^{-2} \mathrm{mR}^{-1}$ dan massa total alat $322,323 \mathrm{Kg}$ Desain kolimator dengan sumber netron Generator netron yang dihasilkan telah memenuhi persyaratan standar untuk digunakan dalam 
NDT. Namun kontaminasi fluks netron cepat masih cukup tinggi sehingga masih diperlukan penelitian lebih lanjut untuk mengurangi fluks netron cepat yang dihasilkan dengan tetap mempertahankan nilai fluks netron thermal di atas $10^{3} \mathrm{n} \cdot \mathrm{cm}^{-2} \cdot \mathrm{s}^{-1}$. Dengan demikian fluks netron generator netron dapat dimanfaatkan untuk radiografi netron sesuai dengan batasan bahwa fluks netron termal yang dihasilkan antara $10^{1}$ sampai dengan $10^{4} \mathrm{n} \cdot \mathrm{cm}^{-2} . \mathrm{s}^{-1}$.

\section{UCAPAN TERIMA KASIH}

Kami mengucapkan terima kasih kepada Drs. Ilham Yazid yang telah share terhadap MCNP-4C code, Dr. Andang Widiarto yang telah membantu menggunakan fasilitas laboratorium komputer di T.Fisika UGM, Ir. Agus Budi Wiyatna, M.Si yang telah menguji hasil perhitungan.

\section{DAFTAR PUSTAKA}

1. http://www.dephub.go.id/udara/dsku/accident data.html\#air carriers trafic data.

2. YOHANNES SARDJONO, ANDANG WIDIHARTO dan YAKOBUS KUSUMA WINATA, "Desain Kolimator Sebagai Penyediaan Berkas Radiografi Netron Dengan Sumber Pu-Be", Prosiding Pertemuan dan Presentasi IImiah Penelitian Dasar IImu Pengetahuan dan Teknologi Nuklir, Pusat Teknologi Akselerator dan Proses Bahan-BATAN, Yogyakarta tanggal 10 Juli 2006.

3. BRIESMEISTER, J.F., MCNP-A General Monte Carlo N-Particle Transport Code, Manual Program, versi 4B, Los Alamos Laboratory, 1997. 